\section{An Effective Method for Co-isolating Nucleic Acids from Horticultural Aroids}

\author{
Stacie L. Aragon, Keng-Chang Chuang ${ }^{2}$, and Adelheid R. Kuehnle ${ }^{1}$ \\ University of Hawaiiat Manoa, Department of Tropical Plant and Soil Sciences, \\ 3190 Maile Way, Honolulu, HI 96822-2279
}

Additional index words. Araceae, Anthurium, Colocasia, DNA, RNA, Spathiphyllum, taro

\begin{abstract}
Isolation of high quality nucleic acids from aroids can be difficult due to the presence of carbohydrates, phenolics, and other compounds that bind to and/or co-precipitate with the DNA or RNA. Methods previously used for marine algae, mango, and papaya were modified and successfully used for the simultaneous isolation of high quality genomic DNA and RNA from Anthurium, Colocasia, and Spathiphyllum leaves. Genomic DNA yields averaged $477 \mu \mathrm{g} \cdot \mathrm{g}^{-1}$ fresh weight for Anthurium and 322 and $177 \mu \mathrm{g} \cdot \mathrm{g}^{-1}$ fresh weight, respectively, for Colocasia and Spathiphyllum. Total RNA yields averaged $129 \mu \mathrm{g} \cdot \mathrm{g}^{-1}$ fresh weight for Anthurium and 61 and $50 \mu \mathrm{g} \cdot \mathrm{g}^{-1}$ fresh weight, respectively, for Colocasia and Spathiphyllum. This method may be useful in co-isolating high quality nucleic acids from additional aroids and other plants.
\end{abstract}

Extraction of DNA and RNA from plant tissues is often accompanied by complex carbohydrates and phenolics that bind to or co-precipitate with nucleic acids and proteins (Loomis, 1974) and can interfere with subsequent analytical procedures. The CTAB (cetyltrimethylammonium bromide) protocol (Doyle and Doyle, 1990) is a popular method used to eliminate complex carbohydrates during simultaneous isolation of DNA and RNA from many plant species. To date the CTAB protocol has been effective for Anthurium and other Araceae DNA (Cho and Palmer, 1999; Kuehnle et al., 2001) but may not completely remove polysaccharides to produce the quantity and quality needed for downstream applications (Buldewo and Jaufeerally-Fakim, 2002). Other methods used in Anthurium DNA isolation utilize buffers containing SDS (Buldewo and Jaufeerally-Fakim, 2002; Chen and Kuehnle, 1996) or sarkosyl (Ranamukhaarachchi et al., 2001) and proved suitable for RAPDPCR and Southern analyses. Utility of these methods with other horticultural aroids and for co-isolation of genomic DNA and RNA are unreported.

Standard protocols for RNA purification, including use of guanidine isothiocyanate, Trizol ${ }^{\circledR}, 2$-butoxyethanol, and a method using polyvinylpyrrolidone (Champagne and Kuehnle, 2000), all yielded degraded or impure RNA. We report here that a newly modified protocol, originally utilized for marine algae (Su and Gibor, 1988) and modified for mango and papaya (Lopez-Gomez and Gomez-Lim, 1992; Mason and Botella, 1997), is highly reproducible for obtaining high quality nucleic acids from Anthurium, Colocasia, and Spathiphyllum. RNA is isolated without

Received for publication 16 May 2003. Accepted for publication 12 Sept. 2003.

${ }^{1}$ To whom reprint requests should be addressed. E-mail: heidi@hawaii.edu

${ }^{2}$ Current address: Floriculture Research Center,

TARI, 1-10 Mayuan Village, Ku-Keng, Yun Lin, Taiwan 646, R.O.C.

HortScience, Vol. 39(1), February 2004
${ }^{\circ} \mathrm{C}$. All equipment, including Oakridge tubes, mortar and pestles, and spatulas, used in this protocol were washed with $1 \% \mathrm{v} / \mathrm{v}$ Absolve (NEN Life Science Products, Boston), rinsed with DEPC-dd $\mathrm{H}_{2} \mathrm{O}$, and autoclaved prior to use. A $10 \times$ MOPS stock was prepared with 0.2 M MOPS [3-( $N$-morpholino) propanesulfonic acid], $0.05 \mathrm{M}$ sodium acetate, $0.01 \mathrm{M} \mathrm{Na}{ }_{2}$ EDTA, adjusted to $\mathrm{pH} 7.0$ with $\mathrm{NaOH}$, filter sterilized, and stored at $4{ }^{\circ} \mathrm{C}$. Glass beads were purchased from Biospec Products (Bartlesville, Okla.; \#11079125).

The absorbance of DNA and RNA preps was determined using a Shimadzu UV160U UV-Vis scanning spectrophotometer (Allometrics, Baton Rouge, La.).

\section{Nucleic acid extraction protocols}

Large-scale nucleic acid isolation.

1) Per $1 \mathrm{~g}$ of aroid leaf tissue, $9.9 \mathrm{~mL}$ of nucleic acid extraction buffer and $0.1 \mathrm{~mL} 2$ mercaptoethanol ( $1 \% \mathrm{v} / \mathrm{v}$ final concentration) was aliquoted into an Oakridge tube.

2) Tissue was ground to a fine powder, added to the extraction buffer, inverted gently but thoroughly for $1 \mathrm{~min}$. Ethanol $(0.25 \mathrm{vol})$ and $5 \mathrm{~m}$ potassium acetate $(0.11 \mathrm{vol})$ were added directly to the sample and inverted for $1 \mathrm{~min}$. This was followed by the addition of 1 vol 24 chloroform : 1 isoamyl alcohol to the tube, with gentle inversion for an additional minute. The tubes were then centrifuged at $39,000 \mathrm{~g}$ (maximum) for $30 \mathrm{~min}$.

3) Supernatant was transferred to a clean

Plant materials. Fully expanded leaf blades were harvested from greenhousegrown wild-type Anthurium 'Paradise Pink' Hort., a Hawaiian taro, Colocasia esculenta, of the 'Lehua' group, and Spathiphyllum 'Petite'. Tissue was also used from Anthurium 'Paradise Pink' Hort. transgenic for Shiva-1 (T.M. Fujii, 2002). Samples were frozen immediately in liquid nitrogen and either stored at $-80{ }^{\circ} \mathrm{C}$ until extraction was performed or used immediately. Samples were weighed out prior to grinding in liquid nitrogen in 1-g or 50-mg quantities for large-scale and minipreps, respectively.

Reagents and equipment. Chemicals were purchased from Fisher Scientific (Fairlawn, N.J.) unless otherwise noted. All reagents were made with distilled deionized water $\left(\mathrm{ddH}_{2} \mathrm{O}\right)$. Reagents used for RNA procedures were made with $\mathrm{ddH}_{2} \mathrm{O}$ that was treated with $0.05 \% \mathrm{v} / \mathrm{v}$ diethylpyrocarbonate (DEPC) and then autoclaved. All prepared solutions were autoclaved before use with the exception of those containing ethanol.

Nucleic acid extraction buffer was $150 \mathrm{~mm}$ Tris base, $50 \mathrm{~mm}$ EDTA, and 2\% w/v SDS, adjusted to $\mathrm{pH} 7.5$ with boric acid. Fresh saturated phenol (Fisher \#BP1750I, pH 7.9 for combined RNA/genomic DNA preps; Fisher \#BP1751; pH 4.3 for RNA only preps) was used for organic extractions. For large-scale preparations, centrifugation was performed in a Sorval RC-5B centrifuge (Beckman Coulter, Fullerton, Calif.) using a SS-34 rotor and Nalgene Oakridge polypropylene tubes (Fisher \#05-529-1D) at $4{ }^{\circ} \mathrm{C}$. Small-scale centrifugations were performed in an Eppendorf 5417R (BioRad, Hercules, Calif.) at 4 tube, and extracted with an equal volume of phenol : chloroform : isoamyl alcohol, then inverted gently but thoroughly for $1 \mathrm{~min}$. Phases were separated by centrifugation and followed by 3 to 4 additional phenol : chloroform : isoamyl alcohol extractions until no precipitate was visible at the interface. If a significant loss of aqueous volume occurred during the extractions, the volume was replenished with additional nucleic acid extraction buffer.

4) The supernatant was transferred to a clean tube, 2.25 vol ethanol added, mixed well, and incubated for $2 \mathrm{~h}$ at $-20^{\circ} \mathrm{C}$.

5) The sample was then centrifuged, the supernatent discarded, and the pellet washed with $10 \mathrm{~mL} \mathrm{70 \%} \mathrm{v/v} \mathrm{ethanol.} \mathrm{The} \mathrm{sample} \mathrm{was}$ centrifuged again and washed for a second time using another $10 \mathrm{~mL} \mathrm{70 \%} \mathrm{v/v} \mathrm{ethanol.}$

6) Pellets were air-dried for $20 \mathrm{~min}$ at room temperature, then resuspended in 10 $\mathrm{mL}$ DEPC-ddH $\mathrm{H}_{2} \mathrm{O}$. $\mathrm{LiCl}$ was added to give a final concentration of $2 \mathrm{M} \mathrm{LiCl}$ and incubated at $-20{ }^{\circ} \mathrm{C}$ overnight.

7) After centrifugation, supernatant was transferred to a fresh tube to continue with the genomic DNA preparation, step 8a. The pellet was used to isolate RNA, step 8b.

Genomic DNA isolation. Note: Gentle inversion was used for all mixing steps.

8a) A $2.5 \mathrm{vol} 95 \% \mathrm{v} / \mathrm{v}$ ethanol was added to the step 7 supernatent and incubated at -20 ${ }^{\circ} \mathrm{C}$ for $1 \mathrm{~h}$.

9a) The sample was than centrifuged at $27,000 \mathrm{~g}$ for $30 \mathrm{~min}$ and the pellet washed $2 \times$ with $70 \% \mathrm{v} / \mathrm{v}$ ethanol.

10a) The pellet was air-dried at room 
temperature for $20 \mathrm{~min}$, resuspended in 398 $\mu \mathrm{L} \mathrm{H}_{2} \mathrm{O}$, and transferred to a $1.5-\mathrm{mL}$ microcentrifuge tube.

11a) Two microliters of RNAseA (10 $\mathrm{mg} \cdot \mathrm{mL}^{-1}$ ) was added followed by a 15 -min incubation at $37^{\circ}$.

12a) Sodium acetate ( $0.1 \mathrm{vol}, 3 \mathrm{~m}, \mathrm{pH} 5.5)$ was added, mixed well, and 2.5 vol ethanol added. The samples were then incubated at $-20{ }^{\circ} \mathrm{C}$ for $30 \mathrm{~min}$.

13a) After incubation, the samples were centrifuged at $27,000 \mathrm{~g}$ for $30 \mathrm{~min}$; then the pellet was washed $2 \times$ with $70 \%$ v/v ethanol.

14a) Pellets were air-dried a final time at room temperature for $20 \mathrm{~min}$. The genomic DNA pellet was then resuspended in 200-300 $\mu \mathrm{L}$ TE buffer.

RNA isolation. Note: If only RNA was to be isolated, saturated phenol $\mathrm{pH} 4.3$ was used in step 3. This decreased any genomic DNA contamination and increased the RNA quality. "RNA only" preps were shaken vigorously in steps $1-7$, rather than gently inverted.

8b) Pellets from step 7 were washed $2 x$ with $70 \% \mathrm{v} / \mathrm{v}$ ethanol.

9b) The RNA pellets were then air-dried at room temperature for $20 \mathrm{~min}$, resuspended in $0.4 \mathrm{~mL}$ DEPC-dd $\mathrm{H}_{2} \mathrm{O}$, and transferred to a 1.5-mL microcentrifuge tube.

10b) A 0.1 vol 3 m sodium acetate $\mathrm{pH} 5.5$ was added, mixed well, followed by the addition of a $2.5 \mathrm{vol}$ ethanol. The sample was then incubated at $-80{ }^{\circ} \mathrm{C}$ for $20 \mathrm{~min}$.

11b) After centrifugation at $27,000 \mathrm{~g}$ for $30 \mathrm{~min}$, the pellet was washed $2 \times$ with $70 \%$ $\mathrm{v} / \mathrm{v}$ ethanol.

12b) The RNA pellet was air-dried at room temperature for $20 \mathrm{~min}$ and resuspended in 25 $\mu \mathrm{L}$ of DEPC-ddH $\mathrm{H}_{2} \mathrm{O}$.

$R N A$ and genomic DNA small-scale preparation. Starting material consisted of $50 \mathrm{mg}$ of tissue ground in liquid nitrogen in $1.5-\mathrm{mL}$ microcentrifuge tubes using micropestles and glass beads. The reagent ratios, centrifuge speeds, and timing were kept identical to those of the large-scale preparation; however, the reagent volumes were scaled down to accommodate the usage of $1.5-\mathrm{mL}$ microcentrifuge tubes for the entire procedure. The final pellets for RNA and genomic DNA were resuspended in 10 and $30 \mu \mathrm{L} \mathrm{DEPC}-\mathrm{ddH}_{2} \mathrm{O}$, respectively.

Determination of DNA and RNA quantity and quality. DNA or RNA was diluted 1:500 and the absorbance measured as a continuous scan from 200 through $300 \mathrm{~nm}$. Absorbance at $260 \mathrm{~nm}$ was used to calculate DNA or RNA quantity. The absorbance at 260 was then compared to the absorbance at 230 and $280 \mathrm{~nm}$ as indicators of purity.

Genomic DNA was examined by electrophoresis in a $0.6 \% \mathrm{w} / \mathrm{v}$ agarose gel using standard TAE electrophoresis protocols (Sambrook and Russell, 2001). The DNA quantity and quality obtained by co-isolation were compared to results from the CTAB method (Doyle and Doyle, 1990) and commercial kits by Qiagen (DNeasy Plant Kit; Valencia, Calif.) and Promega (Wizard Genomic DNA Purification Kit; Madison, Wis.). A minimum of four samples were used for each method, except for two samples used per each kit, to
Table 1. Comparison of genomic DNA yields and purity based on absorbance ratios for the isolation of genomic DNA from Anthurium, Colocasia, and Spathiphyllum by various method.

\begin{tabular}{lccc}
\hline & Co-isolation $^{\mathrm{z}}$ & CTAB $^{\mathrm{y}}$ & Commercial kits $^{\mathrm{x}}$ \\
\hline DNA yield ug. ${ }^{-1}$ fresh weight tissue & & & \\
$\quad$ Anthurium & 477 & 75 & 13 \\
$\quad$ Colocasia & 322 & 50 & $\mathrm{nd}$ \\
$\quad$ Spathiphyllum & 177 & 77 & $\mathrm{nd}$ \\
Absorbance 260/280 ratio & & & \\
$\quad$ Anthurium & 1.9 & 1.9 & 1.5 \\
$\quad$ Colocasia & 1.9 & 1.9 & $\mathrm{nd}$ \\
$\quad$ Spathiphyllum & 2.0 & 1.9 & $\mathrm{nd}$ \\
Absorbance 260/230 ratio & & & \\
$\quad$ Anthurium & 2.0 & 1.2 & 0.9 \\
$\quad$ Colocasia & 1.9 & 1.3 & $\mathrm{nd}$ \\
$\quad$ Spathiphyllum & 1.9 & 1.6 & $\mathrm{nd}$ \\
\hline
\end{tabular}

${ }^{2}$ DNA/RNA Co-isolation method.

${ }^{y}$ Cetyltrimethylammonium bromide method.

${ }^{\times}$Qiagen DNeasy Plant Kit and Promega Wizard Genomic DNA Purification Kit.

nd $=$ not determined.

determine average values. Total RNA was examined by electrophoresis in a $1.5 \% \mathrm{w} / \mathrm{v}$ denaturing agarose gel using the method outlined in Champagne and Kuehnle (2000). The RNAquantity and quality obtained by co-isolation were compared to results from a method using polyvinylpyrrolidone (Champagne and Kuehnle, 2000). A minimum of four samples was used for each method to determine average values. RT-PCR was performed using a standard RT-PCR protocol from Sambrook and Russell (2001). Primers to the Shiva-1 peptide coding sequence were used (T.M. Fujii and A.R. Kuehnle, unpublished).

\section{Results}

$D N A$. The quantity of DNA was determined using an equivalence of $50 \mu \mathrm{g} \cdot \mathrm{mL}^{-1}$ doublestranded DNA per absorbance unit at $260 \mathrm{~nm}$ (Sambrook and Russell, 2001). Comparison of DNA quantity of the co-isolation method with other methods shows that for Anthurium this method has a much higher yield at $477 \mu \mathrm{g} \cdot \mathrm{g}^{-1}$ fresh weight than CTAB or commercial kits at 75 and $13 \mu \mathrm{g} \cdot \mathrm{g}^{-1}$ fresh weight, respectively (Table 1).Colocasia also had high yields for the co-isolation method at $322 \mu \mathrm{g} \cdot \mathrm{g}^{-1}$ fresh weight, with only $50 \mu \mathrm{g} \cdot \mathrm{g}^{-1}$ for the CTAB method. Spathiphyllum yields were $177 \mu \mathrm{g} \cdot \mathrm{g}^{-1}$ for the co-isolation method and $77 \mu \mathrm{g} \cdot \mathrm{g}^{-1}$ for CTAB. Yields were considered so low for commercial kits when applied to Anthurium that the other aroids, Colocasia and Spathyiphillum, were not tested using these methods.

The quality of the genomic DNA recovered was first assessed by its 260/280 and 260/230 absorbance ratios. The absorbance ratios were 1.9 or higher for the co-isolation method. The CTAB method had values of 1.9 for the 260/ 280 , indicating the samples were relatively free of protein, but the 260/230 ratios indicated polysaccharide or polyphenolic contamination, with values of 1.2 through 1.6. The commercial kits (only Anthurium tested) had lower values of 1.5 for $260 / 280$ and 0.9 for $260 / 230$. Although the values of the commercial kits are low and indicative of low quality, this was not the case when the samples were visualized on a gel or when used for downstream applications (data not shown). DNA was also assessed by the ap- $\begin{array}{llllll}1 & 2 & 3 & 4 & 5 & 6\end{array}$

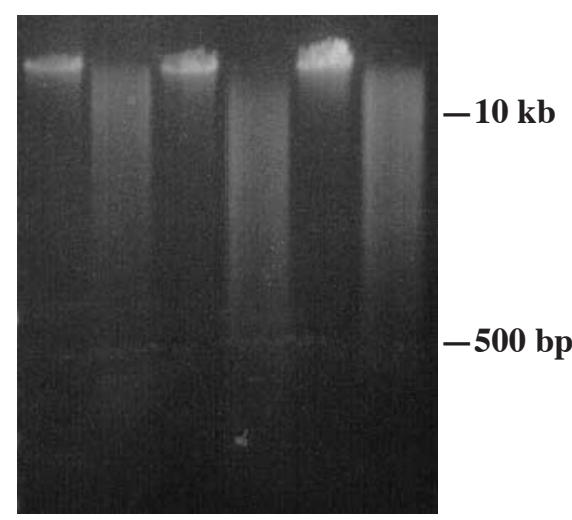

Fig. 1. Electrophoresis of genomic DNA extracted from aroid leaf blades. Aroid genomic DNA $(10 \mu \mathrm{g})$ was digested by restriction enzymes to demonstrate purity. Lane 1, Anthurium 'Paradise Pink' Hort. undigested; Lane 2, Anthurium 'Paradise Pink' Hort. EcoRI digested; Lane 3, Colocasia esculenta 'Lehua' undigested; Lane 4, Colocasia esculenta 'Lehua' EcoRI digested; Lane 5, Spathiphyllum 'Petite' Hort. undigested; Lane 6, Spathiphyllum 'Petite' Hort. EcoRI digested.

pearance of uncut and enzyme-digested nucleic acids on an agarose gel (Fig.1). A band of high molecular weight was visualized for the uncut genomic DNA, while the digested genomic DNA showed an absence of the same high molecular band and a corresponding smear from high to low molecular weights, as would be expected for well-digested DNA. The high-speed spins employed during isolation served to accumulate the contaminating material more tightly at the phenol-chloroform interface, significantly reducing their carryover in subsequent steps.

$R N A$. The quantity of RNA was determined using an equivalence of $38 \mu \mathrm{g} \cdot \mathrm{mL}^{-1} \mathrm{RNA}$ per absorbance unit at $260 \mathrm{~nm}$ (Sambrook and Russell, 2001). RNA yields were greatly improved with the co-isolation method, compared with the polyvinylpyrrolidone method (Table 2). The average amount of total RNA isolated using the co-isolation method was $129 \mu \mathrm{g} \cdot \mathrm{g}^{-1}$ fresh weight for Anthurium, $61 \mu \mathrm{g} \cdot \mathrm{g}^{-1}$ for Colocasia, and $50 \mu \mathrm{g} \cdot \mathrm{g}^{-1}$ for Spathiphyllum. In compari- 
Table 2. Comparison of RNA yields and absorbance ratios, as an indicator of purity, between two different methods of RNA isolation from Anthurium, Colocasia, and Spathiphyllum.

\begin{tabular}{lcc}
\hline & Co-isolation $^{2}$ & Polyvinylpyrrolidone \\
\hline RNA yield $\mu{\mathrm{g} \cdot \mathrm{g}^{-1}}^{\text {fresh weight tissue }}$ & & \\
$\quad$ Anthurium & 129 & 20 \\
Colocasia & 61 & 10 \\
$\quad$ Spathiphyllum & 50 & 12 \\
Absorbance 260/280 ratio & & \\
$\quad$ Anthurium & 1.9 & 0.8 \\
Colocasia & 2.0 & 1.6 \\
Spathiphyllum & 1.9 & 1.0 \\
Absorbance 260/230 ratio & & \\
Anthurium & 2.0 & 0.7 \\
Colocasia & 1.9 & 1.0 \\
Spathiphyllum & 2.1 & 1.0 \\
\hline
\end{tabular}

${ }^{2}$ DNA/RNA co-isolation method.

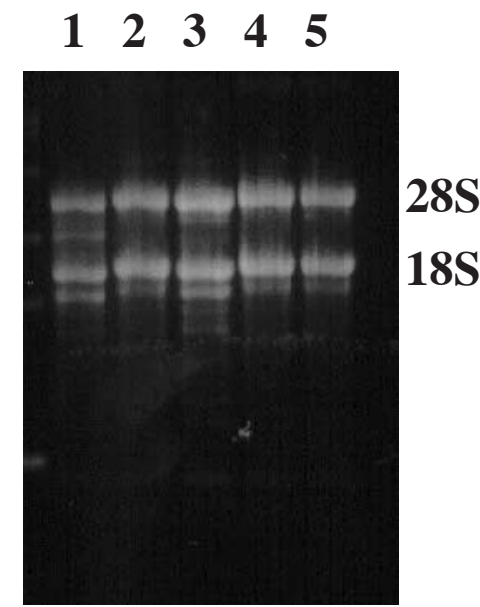

Fig. 2. Electrophoresis of total RNA extracted from aroid leaf blades. Total RNA $(10 \mu \mathrm{g})$ was separated on a denaturing agarose gel, with the $28 \mathrm{~S}$ and $18 \mathrm{~S}$ ribosomal RNA bands indicated. Lanes 1-2, Colocasia esculenta 'Lehua' RNA; Lane 3, Anthurium 'Paradise Pink' Hort. RNA; Lanes 4-5, Spathiphyllum 'Petite' Hort. RNA.

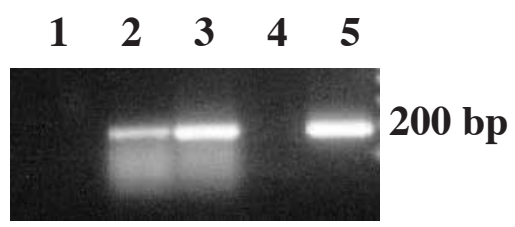

Fig. 3. RT-PCR of wild-type and transgenic anthurium cultivars using primers for the Shiva-1 transcript. Lane 1, Wild-type Anthurium 'Paradise Pink' Hort.; Lanes 2 and 3, Anthurium 'Paradise Pink’ Hort. Shiva-1 transformants; Lanes 4, PCR negative control, no nucleic acid; Lane 5, PCR positive control, plasmid pBPRS1.

2002, and A.R. Kuehnle et al., unpublished) and RT-PCR. The quality of the total RNA was such that only $25 \%(250 \mathrm{ng})$ was needed in RT-PCR for detection of positives, compared to the amount needed using previous total RNA isolation methods. This RNA could be stored for over one year at $-80^{\circ} \mathrm{C}$ and still be useful in RT-PCR analysis. The co-isolation protocol is effective in recovering genomic DNA and RNA of sufficient quantity and quality from Anthurium and other aroid leaves for further analysis.

We have found this procedure to be very useful for the isolation of both RNA and DNA in large- and small-scale preps from several horticultural aroids. This procedure, or modifications of it, may be useful with other tissues that do not respond well to the newer phenolfree procedures for nucleic acid extraction.

\section{Literature Cited} sodium borate, lithium chloride, and ethanol precipitation, and another using polyvinylpyrrolidone (Champagne and Kuehnle, 2000). These procedures all produced degraded RNA and were unsuitable for downstream applications.

Recovery of nucleic acids from aroid leaf tissue is difficult, owing to the elevated quantities of polysaccharides and polyphenols. We Russell, 2001). The CTAB method could yield $260 / 280$ ratios as high as the co-isolation ratios obtained here, but with much lower yields and low 260/230 ratios. Electrophoresis also demonstrated that the co-isolated genomic DNA was of high molecular weight, was not degraded, and that the DNA was easily digested using restriction enzymes. The CTAB genomic DNA had some degradation and was not always easily digested by restriction enzymes (data not shown). The RNA isolated was not degraded, as evidenced by the intact ribosomal bands and lack of smearing. The nucleic acids derived from the modified procedure reported here were used successfully for Northern blotting (Fujii,
Buldewo, S. and Y.F. Jaufeerally-Fakim. 2002.
Isolation of clean and PCR-amplifiable DNA from Anthurium andraeanum. Plant Mol. Biol. Rptr. 20:71a-71g.

Champagne, M.M. and A.R. Kuehnle. 2000. An effective method for isolating RNA from tissues of Dendrobium. Lindleyana 15:165-168.
Chen, F.C. and A.R. Kuehnle. 1996. Obtaining 
transgenic Anthurium through Agrobacteriummediated transformation of etiolated internodes.

J. Amer. Soc. Hort. Sci. 121:47-51.

Cho, Y. and J.D. Palmer. 1999. Multiple acquisitions via horizontal transfer of a group I intron in the mitochondrial coxl gene during evolution of the Araceae family. Mol. Biol. Evol. 16:1155-1165.

Doyle, J.J. and J.L. Doyle. 1990. Isolation of plant DNA from fresh tissue. Focus 12:13-15.

Fujii,T.M. 2002. Evaluation of transgenic Anthurium expressing the shiva-1 gene encoding a synthetic antimicrobial peptide. MS Thesis, Univ. of Hawaii, Honolului.

Hall, T.C., B.U. Buchbinder, J.W. Pyne, S.M. Sun, and F.A. Bliss. 1978. Messenger RNA for G1 protein of french bean seeds: Cell-free translation and product characterization. Proc. Natl. Acad. Sci. (USA) 75:3196-3200.

Kuehnle, A.R., F.C. Chen, and N.C. Sugii. 2001. Transgenic Anthurium, p. 3-15. In: Y.P.S. Bajaj (ed.). Biotechnology in agriculture and forestry, Vol. 48, Transgenic crops. Springer Verlag, Berlin.

Loomis, W.D. 1974. Overcoming problems of phenolics and quinones in the isolation of plant enzymes and organelles. Meth. Enzymol. 31: 528-545.

Lopez-Gomez, B. and M.A. Gomez-Lim. 1992. A method for extracting intact RNA from fruits rich in polysaccharides using ripe mango mesocarp. HortScience 27:440-442.

Manning, K. 1991. Isolation of nucleic acids from plants by differential solvent precipitation. Anal.
Biochem. 195:45-50.

Mason, M.G. and J.R. Botella. 1997. Identification and characterisation of two 1-aminocyclopropane-1-carboxylate (ACC) synthase cDNAs expressed during papaya (Carica papaya) fruit ripening. Aust. J. Plant Physiol. 24:239-244.

Ranamukhaarachchi, D.G., R.J. Henny, C.L. Guy, and Q.B. Li. 2001. DNA fingerprinting to identify nine Anthurium pot plant cultivars and examine their genetic relationship. HortScience $36: 758-760$

Sambrook, J. and D.W. Russell. 2001. Molecular cloning a laboratory manual. 3rd ed. Cold Spring Harbor Lab. Press, Woodbury, N.Y.

$\mathrm{Su}, \mathrm{X}$. and A. Gibor. 1988. A method for RNA isolation from marine macro-algae. Anal. Biochem. 174:650-657. 